\title{
Expectations for the Future Life of Floating People in Mega-Cities: A Study of In-Migrants in Beijing, China
}

\author{
Lei Hu*, Shengnan Liu, Zhiqiang Yan, Yishuang Liu \\ School of Management and Engineering, Capital University of Economics and Business, Beijing, China \\ Email: *leihu0705@163.com
}

How to cite this paper: Hu, L., Liu, S. N., Yan, Z. Q., \& Liu, Y. S. (2020). Expectations for the Future Life of Floating People in Mega-Cities: A Study of In-Migrants in Beijing, China. Psychology, 11, 1315-1339. https://doi.org/10.4236/psych.2020.119085

Received: August 17, 2020

Accepted: September 19, 2020

Published: September 22, 2020

Copyright $\odot 2020$ by author(s) and Scientific Research Publishing Inc. This work is licensed under the Creative Commons Attribution International License (CC BY 4.0).

http://creativecommons.org/licenses/by/4.0/

\section{(c) (i) Open Access}

\begin{abstract}
This paper aims to contribute to the theorisation of the expectations for the future life (EFL) of floating people whose household registration books (hukou) are not registered locally in China's mega-cities. Although the EFL of many rural-urban migrants is explicit, the EFL type of other floating cohorts such as educated migrants and the formation mechanism of EFL of floating people are much less well understood. We argue that EFL is a person's pre-judgment or estimation of living conditions in the future based on his/her perception of current human well-being or utility of life and its main concern is whether he/she expects to live in the mega-city in the future. Based on the social production functions (SPF) theory, three types of EFL for floating population are identified by using data collected from in-depth interviews with 30 Beijing's migrants. This paper reveals that the EFL of floating population is formed by comparing their current actual utility of life with the "normative utility" in the specific life course stage, which is the life utility that people should have in their specific life course stage expected by the society. Finally, these findings are checked out that the theoretical saturation has been reached by applying another 9 copies of transcripts of interviewees.
\end{abstract}

\section{Keywords}

Expectations for the Future Life, Floating People, Migrants, Life Course Stage, Utility of Life, Mega-Cities

\section{Introduction}

The economic and social factors, though important predictors, do not fully explain why people migrate (Van Dalen \& Henkens, 2012, 2013). In recent literature, the person-level factors, including expectations, have also been confirmed 
as predictors of migration decision-making (De Jong, 2000; Boneva \& Frieze, 2001; Tabor \& Milfont, 2011; Jasinskaja-Lahti \& Yijälä, 2011; Hoppe \& Fujishiro, 2015). Expectations for various aspects of living conditions in the future or the whole future life has been paid more and more attention in recent studies on internal migration (Plane et al., 2005; Stockdale et al., 2013; Stockdale, 2016) and international migration (Van Dalen \& Henkens, 2012). Additionally, the expectations for the future life of potential migrants to mega-cities (De Jong, 2000) and of rural-urban migrants in mega-cities in developing economies ( $\mathrm{Li}, 2003$ ) have received special attention. However, it is not clear what the expectations for the future life of other floating cohorts such as educated migrants is, furthermore, the formation mechanism of the expectations for the future life is much less well understood.

This paper aims to investigate the types of expectations for the future life (EFL) of floating people in China's mega-cities and reveal its formation mechanism, making several contributions to the literature. There are a few reasons why it is important to look into this topic. First, mega-cities are the engines of regional and national economic growth (Castells, 1996: p. 434) and central and local governments in China have been increasingly regarding the magnitude and structure of urban population as key policy variables having impacts on the economic and social development of mega-cities, namely Beijing, Shanghai, Guangzhou and Shenzhen ${ }^{1}$. If EFL outcomes could be a critical indicator to predict migrants' decisions of re-migration, policy-driven changes in migrants' EFL may affect individual outmigration decisions and ensuing outmigration flows, which contribute to the change of population magnitude and structure of mega-cities. Besides, by getting a better understanding of the living conditions that are important to migrants through the knowledge of their EFL, policymakers could take some measures to promote public services for migrants.

Second, on the theoretical front, different from western society, China has a unique management system of household registration books (hukou). Moreover, the hukou system is more strictly enforced in mega-cities than in other cities, making it crucial hard for migrants to acquire local hukou, which is the necessary document to own in order to be enrolled in local schools (Li et al., 2010; He, 2014: pp. 44-45). It is the lack of local hukou that often plays a decisive role in shaping the EFL of migrants in mega-cities (Li, 2003; Hu et al., 2011; He, 2014: pp. 44-45). Thus, the findings drawn from the research of mega-cities in this paper could provide theoretical clues for the future comparative study of Chinese and Western migrants' EFL.

Third, theoretically, the existing literature shows the importance of the expectations for the future life in the decision-making process of population migration. Rational economic actors make decisions to migrate to expect a positive net return, usually measured by income (Todaro, 1976; Gao \& Smyth, 2010), job ${ }^{1}$ Please refer to the economic and social development planning outlines of Beijing, Shanghai, Guangzhou and Shenzhen in the past decade, which are available on the official websites of these cities. 
opportunities (Blejer \& Goldberg, 1980; Borjas \& Bratsberg, 1996; Van Dalen \& Henkens, 2012), job benefits (Hoppe \& Fujishiro, 2015) and housing conditions (Blejer \& Goldberg, 1980). Meanwhile, from the perspective of life course, the expectations for the life in the next life course stage could be a driving factor for migrants to adjust living conditions through migration (Plane et al., 2005; Stockdale et al., 2013; Stockdale, 2016). However, many issues about the connection between EFL and migration decision-making still need to be further studied. Specifically, Li (2003) states that the EFL of most rural-urban migrants in China's mega-cities is to return to their hometowns in the countryside to earn a living rather than settling in mega-cities in the old age, but for a small number of rural-urban migrants with good luck in business or proficient professional skills, they can get enough income to live in mega-cities (He, 2014: pp. 44-45), do they expect to return home to make a living when they are old? If not, what is their EFL? Furthermore, there are many educated migrants with a college degree or above $^{2}$ in mega-cities, they are usually more competitive in the labor market and have higher ability to obtain high income than rural-urban migrants because of their higher education level, so what is their EFL? In a word, how many types of EFL do the migrants with no local hukou, commonly referred as the "floating people" (liudong renkou), in mega-cities have? Furthermore, what is less certain is how migrants' EFL is formed. Indeed, this question has received little academic attention to date. In this paper, we seek to acquire the answers to these questions. In particular, we focus on that whether floating people expect themselves to live in mega-cities to get living conditions in the future.

In this paper, after expounding the importance of studying this topic as above, we first elaborate the meaning of EFL and make a definition for it, which is the logical starting point for the following analysis. Then, for the consideration of methodology, we choose the qualitative analysis method to carry out the research. Thus, utility of life is selected as the theoretical perspective of this study in view of its close association with EFL. The benefits of applying an explicit theoretical perspective are embodied in the use of data collection and analysis methods and the construction of theories, which will be discussed later. In terms of data coding method, this paper uses the method proposed by Pan and his collaborators (Goh et al., 2013; Wang et al., 2014; Pan et al., 2015). Compared with other coding approaches such as grounded theory, Pan's method is structured, which has two advantages (Goh et al., 2013; Wang et al., 2014; Pan et al., 2015): 1) one advantage is that the method applies an explicit theoretical lens to guide the data collection and subsequent analysis, and to induce theoretical innovation based on the existing theoretical lens, which is consistent with the design of this paper using an explicit theoretical perspective of utility of life; 2) another advantage is that the method follows the usual international writing framework, i.e., not to describe the case story in large space, but to pertinently use some case "data" to ${ }^{2}$ In this paper, "educated migrants" are defined as those who have a college degree or above, regardless of whether they come from rural areas or not. While "rural-urban migrants" are defined as the ones from rural areas with educational background below college. 
explain the conclusion. And this method can achieve such an effect that looking at (qualitative) data is like looking at the conclusion, conversely, the (qualitative) data can be seen from the conclusion. Finally, the empirical results of this paper are used to discuss the actual EFL of various floating cohorts.

Correspondingly, the following section elaborates the concept of EFL of floating people in mega-cities. The third section first provides a brief introduction to social production functions (SPF) theory (Lindenberg \& Frey, 1993; Ormel et al., 1997), which is the theoretical lens of this study, and then introduces the data collection process and sample statistics in detail. The fourth section specifies the process of data coding, on which the theoretical model is obtained. The fifth section makes some discussions based on the above empirical results. The sixth section reports the conclusions.

\section{Concept of Expectations for the Future Life}

Literally, expectations for the future life are the judgments or estimations of the future rather than current living conditions by the person. Because expectations is learnt from experience (Carr et al., 2001), a person's expectations of future living conditions is learnt from his/her current living conditions, from which he/she perceives his/her current quality of life. Over the past few decades, the quality of life in metropolis has been a widely research issue. Many studies use a wide number of eclectic variables to define quality of life, including economic, social, environmental, aesthetic, cultural, and amenity related concerns (Liu, 1975; Porell, 1982; Kleiner, 1984). However, the investigation conducted by Furuseth \& Walcott (1990) found that the critical concerns of jobs, educational opportunities, clean air and water, and adequate public facilities could express the meaning of quality of life. Wallace \& $\mathrm{Wu}$ (2018) used the four dimensions of economic well-being, social well-being, healthy living, and urban mobility to measure quality of life in 366 U.S. metropolitan statistical areas, and examined the impact on immigrant concentration and diversity on urban quality of life.

Meanwhile, note here that there are differences between objective quality of life and subjective quality of life (Wish, 1986; Cummins, 2000; Moons et al., 2006). Ferrans (1996) chose the individualistic view to conceptualize the quality of life in nursing and health care. In line with this approach, this paper also adopts the individualistic ideology to specify the quality of life of floating people in mega-cities, because the person is the only proper judge of his/her experience of life in mega-cities. Furthermore, it is most appropriate to conceptualize quality of life in terms of life satisfaction (Furuseth \& Walcott, 1990; Ferrans, 1996; Moons et al., 2006), so this paper uses Ferrans's (1996) definition of quality of life, which is "a person's sense of well-being that stems from satisfaction or dissatisfaction with the areas of life that is important to him/her".

More and more studies have confirmed the theoretical importance and measurement of life satisfaction as an indicator of human well-being. Veenhoven (2017) argued that "life satisfaction", as a synonym of happiness, and "well-being" may be used interchangeably in the broad sense of living a good life. De Jong 
et al. (2002) reported mixed conclusions of the changes of rural-urban migrants' subjective well-being that stemmed from post-move satisfaction with employment situation, living environment, and community facilities in Thailand. Astuti et al. (2015) constructed a model to measure the well-being with reference to the built environment on the case study of Bekasi City in Indonesia, and found that the sustainable housing environmental quality was the core aspect of well-being. Ivlevs (2015) used life satisfaction as a proxy for subjective well-being and found that higher levels of life satisfaction contributed to a higher probability of reporting intentions to move abroad. Morris (2019) used a set of models examining life satisfaction to measure the subjective well-being of city dwellers and suburbanites.

Based on the close and interesting relationship between quality of life, life satisfaction and human well-being, a concept of expectations for the future life $(\mathrm{EFL})$ is proposed in our research. EFL is defined here as a person's pre-judgment or estimation of living conditions in the future based on the perception of current human well-being. Just as the quality of life is made up of many elements, "living conditions" in the definition of EFL include many components, such as jobs, housing, educational opportunities, health care and public facilities.

This paper does not intend to elaborate on the structure and components of living conditions. However, note that a person could change the place of residence to increase the access to the living conditions at destination residence place if he/she expects that it is quite hard to acquire the said living conditions at current residence place. Evidences of this can be found in the literature on relationship between life satisfaction or human well-being and migration decision. Dissatisfaction with one's place or community is a driving force in his/her decision to move (Heaton et al., 1981; Speare et al., 1982; Ge \& Hokao, 2006). The potential migrants in some sense estimate the "expected utility" of the move (Morrill, et al., 1986), and people view the migration decision as one of utility maximization, i.e., they migrate in order to become better off in some subjective sense (Ziegler \& Britton, 1981). In addition, the quality of life has a substantial impact on in-migration volumes to metropolis (Porell, 1982). Similarly, quality of life or life satisfaction considerations are major motivations for leaving metropolitan areas (Williams \& Sofranko, 1979) or emigrating abroad (Graham \& Markowitz, 2011; Van Dalen \& Henkens, 2013; Cai et al., 2014; Chindarkar, 2014; Otrachshenko \& Popova, 2014; Ivlevs, 2015). Hence, in view of the location-related characteristics of access to living conditions, when examining EFL of floating people in mega-cities, we are particularly interested in that whether they expect themselves to live in mega-cities to get living conditions in the future, which will be analyzed in details below.

\section{Methodology}

There are two main reasons for choosing the qualitative analysis method in this paper. First, there is no mature construct, measurement and theoretical hypothesis concerning EFL in the existing literature, so this study aims to contribute to the theorisation of EFL, including examining all types of EFL and revealing its 
formation mechanism. And qualitative research is more effective because of its strength in exploring new conceptual arguments (Siggelkow, 2007). Second, the qualitative analysis method can collect multi-dimensional data on the living conditions of floating people in mega-cities, which will provide detailed raw materials for the study.

\subsection{Theoretical Perspective: Utility of Life}

In view of the close relationship between EFL and human well-being, the utility of life is selected as the theoretical perspective of this study. The utility is an abstract measure of the degree of satisfaction and happiness that people get from their lives (Mankiw, 2012: p. 451). In Lindenberg \& Frey's (1993) social production functions (SPF) theory, utility and psychological well-being are synonyms. According to SPF theory, floating people in mega-cities strive to obtain human well-being or utility of life ${ }^{3}$ through social production, which refers to that people actively create social relationships and participate in social activities. The process of social production is essentially to achieve several levels of life goals, and human well-being is obtained through a series of nested social production functions (Lindenberg \& Frey, 1993; Ormel et al., 1997). Figure 1 gives an overview of this hierarchy.

The social production function describes the relationships of various levels of life goals and basically specifies how a particular person can produce utility of life or psychological well-being. Utility $(U)$ is achieved through two universal goals: physical well-being $(P W)$ and social well-being $(S W)$. Thus, the utility function is $U=f(P W, S W)$. The production function for physical well-being is $P W=f(S T, E C, I C) . S T$ denotes stimulation, which refers to activities that produce arousal including mental and sensory stimulation and physical effort. $E C$ denotes external comfort, referring to the living environment is safe and pleasant. IC means internal comfort, which refers to somatic comfort in terms

Utility of life or human well-being
Universal needs:
Stimulation, external comfort, internal comfort, status,
behavior confirmation, affection
Activities and endowments
Resources: Active resources needed to execute activities
and to obtain endowments (e.g. time, energy and skills)
Latent resources (e.g. inactive kinship, savings)

Figure 1. The hierarchical structure of the elements in social production functions (SPF) theory. Source: Ormel et al., 1997. Quality of life and social production functions: a framework for understanding health effects. Social Science \& Medicine, 45(7): 1051-1063. Slightly modified.

${ }^{3}$ In this paper, we use the terms "human well-being", "psychological well-being" and "utility of life" as synonyms. 
of absence of hunger, thirst, pain, fatigue and other somatic discomforts. The production function for social well-being is $S W=f(S, B C, A) . S$ stands for status, which refers to a relative ranking (mainly based on over scarce resources). $B C$ denotes behavioral confirmation, which is the confirmation of behaviors by others. Especially in the eyes of relevant people, even though the behavior is not directly strengthened, they also feel like they have done the "right thing". $A$ means affection, including love, friendship and emotional support, which are provided for caring relationships (intimate, family, and friendship relations).

The accomplishment of the above instrumental goals is realized through a series of instrumental activities and/or endowments. Instrumental activities refer to social actions, such as working hard to get a certain position. For example, behavior confirmation is often produced by membership in groups $(I)$ and by conformity to norms $(C)$. The production function is thus $B C=f(I, C)$. Endowments is a situation in which instrumental goals can be achieved without any activity. For instance, women can obtain behavior confirmation through marriage without other forms of activities, the reason is that establishing a family and raising children are both the "right things". The lower we go in the hierarchy, the more context-specific the production functions will be.

\subsection{Data}

Data from a survey of in-migrants in Beijing are presented. As the capital of China, Beijing is a typical mega-city with more than 20 million residents. According to Beijing Municipal Bureau Statistics, there were 7.943 million residents without local hukou (floating people) in Beijing in $2017^{4}$. The lack of $h u$ kou has increased these floating people's uncertainty of permanent settlement in Beijing, which is closely associated with the EFL of individuals. Thus, it is suitable to select Beijing to investigate the types of EFL of floating people and its formation mechanisms.

The study adopted the approach of semi-structured interviews with floating people to collect data. Since our study target on employed individuals whose instrument goal of status (Ormel et al., 1997) is usually achieved through work, according to the definition given by National Bureau of Statistics of China that the labor force should be 16 years and older ${ }^{5}$ and China's usual retirement age ( 60 years old), the age of potential interviewees must be in the range of 16 and 60 years old. In other words, dependants are not our targeted interviewees. Similarly, students are excluded from the survey.

\footnotetext{
${ }^{4}$ Although Beijing Municipal Government began to provide the channel of points - based household registration system (jifen luohu) for in-migrants to apply for hukou in April 2018, only a very small number of floating people can successfully acquire the qualification. For instance, in 2019, the number of in-migrants who obtained qualification of jifen luohu accounted for about 5.6\% of the 106403 applicants, only 6007. Details can be obtained via this URL: http://bj.people.com.cn/n2/2019/1016/c82840-33439024.html. ${ }^{5}$ Details can be obtained via this URL: http://www.stats.gov.cn/tjjj/zbjs/201912/t20191202_1713057.html.
} 
Since the sampling frame was not available, we used a mixed sampling technique to recruit participants, involving convenient sampling, purposive sampling and snowball sampling. First, the convenient sampling was conducted when we encountered the respondents who indicated their willingness to participate in the interview at a corner, supermarket or park. Although most of the people we met refused to participate in the interview, 6 interviewees were still conveniently sampled to include a range of education levels (including primary school, junior high school, and senior high school), current age (as a proxy for life course stage) and occupations. Then, 24 interviewees were purposively sampled through the introduction of friends, acquaintances and colleagues in order to cover a wider range of education levels (including secondary school, college, Bachelor, and Master degree) and occupations. Finally, 9 respondents were interviewed via a snowball approach, including asking the initial participants for referrals to eligible members of their acquaintances. These 9 interviews were reserved for later theoretical saturation checkout.

These interviews explored the participants' own experiences of migration into Beijing, post-migration living conditions (including physical condition, job and income, and friendship), senses of life satisfaction in Beijing, and estimations of living conditions in the future. From March to May 2018, the interviews by convenient sampling were conducted face to face at a place of the interviewees' choice and nearly exclusively at their workplaces, with durations ranging from 1 to 1.5 hours. But for purposive sampling and snowball sampling, except for one interview was conducted face to face at the office, other interviews, at the individuals' request, were conducted by telephone. These interviews were conducted between June and September 2018, and each interview lasted about one hour. Our interviews included both 33 single person interviews and 3 couple interviews determined by the interviewees. The interview process used a topic guide to flexibly explore the key research themes, while being open to exploring issues raised by the participants themselves.

The interview researchers were two men under the age of 40 and a woman under 30. The two men, one from Hubei and the other from Liaoning, had lived in Beijing for more than 7 years before they were granted local hukou. The woman is a native of Beijing and has been living in Beijing before our survey. The researchers were trained in qualitative methods before formal interviews and they were reflexively aware of how their identities might influence the kind of statements made to them. Furthermore, all the researchers possessed some of the same experiences of living in Beijing as the participants, which helped to enrich an understanding of accounts.

The face to face interviews were conducted jointly by the male researcher from Hubei origin and the female researcher, and the telephone interviews were conducted separately by the former. All interviews were recorded, transcribed and then coded. Each transcript was sent to the participant for necessary correction before it is coded. In addition, if necessary, the participants would be con- 
tacted in the subsequent coding procedures to clarify some ambiguities in the transcripts. Also, in order to ensure the accuracy of data, the data triangulation was performed, i.e., the qualitative data and research results were mutually checked and audited by the three researchers.

\subsection{Sample}

As shown in Table 1, 39 respondents were interviewed in the study. As previously described, we used the interviews from respondents I\#1 - I\#30 for coding and theoretical construction, while the interviews from respondents I\#31 - I\#39 for theoretical saturation checkout.

Compared with the structures of gender, age, and education level of Beijing's floating population in 2015, which could be drawn from the Dynamic Monitoring Sample Survey of Floating Population released by the former National Health Commission of the P.R. of China (Li, 2017), the sample of 30 respondents has the similar structure. Specifically, the sample includes: 1) almost the same proportion of male (53.3\% vs $51.7 \%$ ); 2 ) lower proportion of individuals below 14 years old ( $0 \%$ vs $19.8 \%$ ), higher proportion of 15 - 64 years old $(96.7 \%$ vs $78.9 \%)$, and almost the same proportion of 65 years old and above $(3.3 \%$ vs $1.3 \%)$; 3 ) almost the same proportion of elementary school (6.6\% vs $7.6 \%)$ and senior high school (20.2\% vs $22.5 \%)$, slightly lower proportion of junior high school (33.2\% vs $38.3 \%$ ), and slightly higher proportion of Bachelor (including college) (33.4\% vs $28.9 \%$ ) and Master (6.6\% vs $2.7 \%)$. Although there are no individuals under the age of 14 in this sample, this is reasonable because people in this age group are generally dependants, which is outside the scope of this study. Note here that, perhaps for the same reason, the proportion of educated migrants with a college degree or above in the sample is higher than in 2015 (40\% vs $31.6 \%$ ). In addition, in terms of the structure of occupation, compared with Beijing's floating population in 2015 ( $\mathrm{Li}, 2017)$, the sample has almost the same percentages of state and social management (3.3\% vs $1.3 \%)$, professional and technical personnel (16.7\% vs $15.6 \%$ ), clerical personnel (3.3\% vs $3.9 \%)$, business service personnel (63.4\% vs $64.0 \%)$ and industrial workers (13.3\% vs $10.9 \%)$. In a word, this sample is well representative.

\section{Empirical Results}

As previously described, we use the method of coding proposed by Pan and his collaborators (Goh et al., 2013; Wang et al., 2014; Pan et al., 2015). Specifically, we carried out the two structured steps of thematic coding and selective coding in turn, which are treated separately below.

The coding was done by the male researcher from Hubei origin and the female researcher. To ensure the concordance of coding, the two coders reached a consensus on the divergent results by fully discussing in the trial coding stage. Furthermore, the researchers checked each other's coding results to reach to an agreement in the formal coding stage. 
Table 1. List of basic information of respondents.

\begin{tabular}{|c|c|c|c|c|}
\hline $\begin{array}{l}\text { Respondent } \\
\text { No. }\end{array}$ & Gender & Age & Occupation & Education level \\
\hline $\mathrm{I} \# 01$ & Female & 47 & Selling children's toys at the ground stand & Primary school \\
\hline $\mathrm{I} \# 02$ & Female & 38 & Sales of brand shoe store & Junior high school \\
\hline I\#03 & Female & 26 & $\begin{array}{l}\text { Head teacher of education and training } \\
\text { company }\end{array}$ & Bachelor \\
\hline I\#04 & Female & 32 & Budget officer of garden budget enterprise & College \\
\hline $\mathrm{I} \# 05$ & Male & 37 & Employee of IT company & Senior high school \\
\hline I\#06 & Male & 35 & $\begin{array}{l}\text { Employee of automotive } \\
\text { manufacturing company }\end{array}$ & Bachelor \\
\hline $\mathrm{I} \# 07$ & Male & 65 & Worker of park greening & Primary school \\
\hline $\mathrm{I} \# 08$ & Female & 42 & $\begin{array}{l}\text { Self-employed in the } \\
\text { building materials industry }\end{array}$ & Junior high school \\
\hline I\#09 & Male & 38 & Owner of a small clothing company & Senior high school \\
\hline I\#10 & Male & 30 & Safety captain in university & Senior high school \\
\hline I\#11 & Male & 33 & Employee of Internet company & Master \\
\hline I\#12 & Female & 27 & Self-employed waste collectors & Junior high school \\
\hline I\#13 & Male & 30 & Self-employed waste collectors & Junior high school \\
\hline I\#14 & Female & 24 & Teacher in private school & Master \\
\hline I\#15 & Male & 25 & Barber of brand shop & Junior high school \\
\hline I\#16 & Male & 27 & Employee of IT company & Bachelor \\
\hline I\#17 & Female & 26 & Nurse in major hospital & Bachelor \\
\hline I\#18 & Male & 56 & Self-employed in business & College \\
\hline I\#19 & Female & 53 & $\begin{array}{l}\text { Unemployed } \\
\text { (formerly guide of supermarket shopping) }\end{array}$ & Senior high school \\
\hline $\mathrm{I} \# 20$ & Male & 43 & Self-employed in decoration industry & Junior high school \\
\hline $\mathrm{I} \# 21$ & Female & 41 & Employee of housekeeping company & Junior high school \\
\hline $\mathrm{I} \# 22$ & Male & 57 & Chairman of private enterprise & Bachelor \\
\hline I\#23 & Female & 39 & Company deputy Finance Manager & Senior high school \\
\hline $\mathrm{I} \# 24$ & Male & 39 & Company full-time driver & Junior high school \\
\hline $\mathrm{I} \# 25$ & Male & 41 & Company workshop worker & Senior high school \\
\hline $\mathrm{I} \# 26$ & Male & 39 & Worker of beauty products company & College \\
\hline I\#27 & Male & 39 & Taxi driver & Junior high school \\
\hline $\mathrm{I} \# 28$ & Female & 34 & Salesmen at pharmacy & College \\
\hline I\#29 & Female & 32 & $\begin{array}{l}\text { General manager of } \\
\text { beauty products company }\end{array}$ & College \\
\hline $\mathrm{I} \# 30$ & Female & 49 & Self-employed in business & Junior high school \\
\hline I\#31 & Male & 35 & Employee of IT company & Master \\
\hline I\#32 & Female & 33 & $\begin{array}{l}\text { Employee of education } \\
\text { and training company }\end{array}$ & College \\
\hline
\end{tabular}




\section{Continued}

\begin{tabular}{ccccc}
\hline I\#33 & Male & 38 & $\begin{array}{c}\text { Employee of automotive } \\
\text { manufacturing company }\end{array}$ & Bachelor \\
I\#34 & Male & 26 & $\begin{array}{c}\text { Employee of safety and protection company } \\
\text { College }\end{array}$ & Bachelor \\
I\#35 & Male & 24 & Logistics staff in university & Bachelor \\
I\#36 & Female & 24 & Logistics staff in university & Bachelor \\
I\#37 & Female & 24 & Administrative staff in university & College \\
I\#38 & Male & 42 & Company safety director & College \\
I\#39 & Male & 45 & Company department manager &
\end{tabular}

Note: 1. Respondents I\#1 - I\#6 were conveniently sampled, respondents I\#7 - I\#30 were purposively sampled, and respondents I\#31 - I\#39 were interviewed via a snowball approach. 2 . Respondents I\#12 and I\#13, I\#18 and I\#19, I\#20 and I\#21 were couple interviewed respectively, others were single person interviewed. Source: Authors' survey.

\subsection{Thematic Coding}

\subsubsection{Concept Categorization}

The thematic coding is carried out simultaneously during the process of data collection. The main task is to conceptualize the content of transcripts first, and then categorize the concepts, i.e., to classify the raw data into "themes" (Goh et al., 2013). Taking the categorization of "expectations for the future life (EFL)" as an example, each respondent expresses his/her living conditions in the future, and these original statements are abstracted into corresponding concepts, which are further abstracted to obtain a category which is named "a person's pre-judgment or estimation of living conditions in the future", that is, "expectations for the future life". Table 2 presents some respondents' raw data to demonstrate this analysis process. By inductive method, we find that there are three types of EFL of floating people, as shown in Table 2.

\subsubsection{Matching the Categories with the Theoretical Lens}

According to the method illustrated by Goh et al. (2013), the categories obtained above needs to be matched with the corresponding theoretical unit and theoretical lens in turn. The theoretical unit is got by subdividing the corresponding theoretical lens (Goh et al., 2013), in other words, the theoretical unit could be regarded as the conceptual sub-category of theoretical lens. Thus, according to SPF theory (Lindenberg \& Frey, 1993; Ormel et al., 1997), the theoretical unit corresponding to utility of life involves two layers: 1) the upper layer includes physical well-being and social well-being; 2) the lower layer includes stimulation, internal comfort, external comfort, status, behavioral confirmation and affection.

Table 3 shows several examples of how the categories are matched with the theoretical lens of utility of life. The results also confirmed that the living utility of floating people in mega-cities is produced by the achievement of multi-level life goals through social production functions (Lindenberg \& Frey, 1993; Ormel et al., 1997). For instance, respondent I\#01' physical well-being is produced at a low level, this is due to the fact that her instrumental goals of stimulation, 
Table 2. Categorization of raw data.

\begin{tabular}{|c|c|}
\hline Category & Snippet of raw data \\
\hline $\begin{array}{l}\text { Pre-judgment or } \\
\text { estimation of living } \\
\text { conditions in the future } \\
\text { (now living in } \\
\text { mega-cities for a period } \\
\text { of time, and then } \\
\text { re-migrating to another } \\
\text { place to live in the future) }\end{array}$ & $\begin{array}{l}\text { I\#07 We plan to earn some money in Beijing now and return to our } \\
\text { hometown later (now living in mega-cities for a period of time, and } \\
\text { then moving back to the countryside in the future). We will return } \\
\text { to our hometown when we cannot work. There are fields in my } \\
\text { hometown, where my son and grandson live. And after returning } \\
\text { home, we can plant, weed and breed and so on to find a source of } \\
\text { income (pre-judgment or estimation of the future living conditions) } \\
\text { I\#12 \& I\#13 We are going to do this job [collecting waste products] } \\
\text { in Beijing for another five or six years, and then return to hometown } \\
\text { to buy a house (living in mega-cities for a period of time, and then } \\
\text { moving to another city). When going home, I am looking for a } \\
\text { formal job of transportation in my hometown, which could bring } \\
\text { me an income of } 5000 \text { to } 6000 \text { yuan a month, and my wife can } \\
\text { take care of children at home. Moreover, my parents could do } \\
\text { farm work and raise some chickens and ducks in hometown } \\
\text { (pre-judgment or estimation of the future living conditions) }\end{array}$ \\
\hline $\begin{array}{l}\text { Pre-judgment or } \\
\text { estimation of living } \\
\text { conditions in the future } \\
\text { (now living in mega-cities } \\
\text { for a period of time, and } \\
\text { then deciding where to } \\
\text { live in the future) }\end{array}$ & $\begin{array}{l}\text { I\#02 The future life in Beijing is very embarrassing. I am not sure } \\
\text { if I am in Beijing in the future. Just go forward step by step } \\
\text { (considering the future after living in mega-cities for a period } \\
\text { of time)... The eldest child has gone to Zhuozhou for school, } \\
\text { and his grandfather takes care of him there. But I still want him to } \\
\text { study in Beijing in the future... But without the Beijing hukou, } \\
\text { it's hard to come back to study (pre-judgment or estimation } \\
\text { of the future living conditions) } \\
\text { I\#17 I will stay in Beijing for a few more years and consider the } \\
\text { future life according to the situation after a few years, I may stay in } \\
\text { Beijing or leave Beijing at that time (considering the future after } \\
\text { living in mega-cities for a period of time). If leaving Beijing, } \\
\text { I will probably go to Wuhan, because my hometown is close to } \\
\text { Wuhan, and the pressure of life in Wuhan is not so great, } \\
\text { and I probably can afford a house. Besides, there are also } \\
\text { many relatives in Wuhan who can help each other } \\
\text { (pre-judgment or estimation of the future living conditions) }\end{array}$ \\
\hline
\end{tabular}

I\#18 \& I\#19 We will stay in Beijing in the future in order to lighten the burden on my children in the future (they will stay in mega-cities in the future). My two daughters have respectively settled in Beijing

Pre-judgment or estimation of living conditions in the future (staying in mega-cities in the future) in 2014 and 2018, and we will stay here to help them take care of their families (pre-judgment or estimation of the future living conditions)

I\#22 I want to work in Beijing in the future and make a little achievement in the pharmaceutical industry. I will not go back to my hometown (he will stay in mega-cities in the future)... My son has been working in Beijing and has obtained the Beijing hukou. My wife and I will live with our son together in Beijing in the future (pre-judgment or estimation of the future living conditions)

Note: Values in the parentheses are initial concepts obtained by abstracting the materials. Source: Authors' arrangement.

internal comfort, and external comfort are all achieved at a low level. Meanwhile, her job is to sell children's toys at the ground stand (the level of status is low), and the level of behavior confirmation and affection are also not high. Therefore, her social well-being is also produced at a low level. Due to the low levels of 
Table 3. The matching of categories with the theoretical lens of utility of life.

\begin{tabular}{|c|c|c|c|}
\hline Theoretical lens & Theoretical unit & Category & Snippet of raw data \\
\hline \multirow{8}{*}{$\begin{array}{l}\text { I\#01's utility of life } \\
\text { (I have no sense of } \\
\text { happiness in Beijing, } \\
\text { and I come to Beijing } \\
\text { just for earning money) }\end{array}$} & Stimulation & $\begin{array}{l}\text { Physical strength, } \\
\text { energy }\end{array}$ & I usually have no time to rest and feel very tired \\
\hline & $\begin{array}{l}\text { Internal } \\
\text { Comfortable }\end{array}$ & $\begin{array}{l}\text { Somatic discomfort } \\
\text { such as fatigue } \\
\text { and hunger }\end{array}$ & $\begin{array}{l}\text { I make toys at home at night and come out to sell them in the } \\
\text { daytime. I come out for a whole day and am not back at noon... } \\
\text { grab a bite to eat usually noodles and dried vegetables... stay here } \\
\text { from morning to night (selling toys). I can't sleep for a long time, } \\
\text { and sometimes bed at one or two o'clock in summer night }\end{array}$ \\
\hline & $\begin{array}{l}\text { External } \\
\text { Comfortable }\end{array}$ & $\begin{array}{l}\text { Living conditions } \\
\text { and environments }\end{array}$ & $\begin{array}{l}\text { The place where I live always needs to be demolished, so I } \\
\text { have been changing places, and I don't have a permanent residence... } \\
\text { Now I live in a yard where the rent is a few hundred yuan per } \\
\text { month and the space is not large. I make my own meals, and } \\
\text { the traffic around is OK. There is a small shop behind the yard if } \\
\text { I need to buy something, which can meet the basic needs of life, } \\
\text { and I usually do not buy anything }\end{array}$ \\
\hline & Status & Occupation & $\begin{array}{l}\text { After coming to Beijing in 2008, I have been selling toys for children, } \\
\text { and because the city management staff always check on us, } \\
\text { I have changed many places to sell toys }\end{array}$ \\
\hline & $\begin{array}{l}\text { Behavioral } \\
\text { confirmation }\end{array}$ & What should be done & $\begin{array}{l}\text { My son and daughter are both in the rural home and they are not } \\
\text { living very well because they can't find any jobs to do... } \\
\text { I am making money in Beijing by myself in order to help them more. } \\
\text { And they don't have any opinions about my work and life }\end{array}$ \\
\hline & Affection & $\begin{array}{l}\text { Interpersonal } \\
\text { communication } \\
\text { and emotions }\end{array}$ & $\begin{array}{l}\text { I feel lonely in Beijing, but there is no way to change such situation... } \\
\text { Usually, my son, daughter and I don't have much contact, } \\
\text { nor do they call, and we only call when something happens, } \\
\text { and never call when nothing happens }\end{array}$ \\
\hline & $\begin{array}{l}\text { Physical } \\
\text { well-being }\end{array}$ & Health conditions & $\begin{array}{l}\text { Ioften feel sick, sometimes I feel pain in my neck and back, } \\
\text { and I always have leg pain and headache }\end{array}$ \\
\hline & $\begin{array}{c}\text { Social } \\
\text { well-being }\end{array}$ & Social relations & $\begin{array}{l}\text { I have no fellow in Beijing, and my son and daughter usually } \\
\text { have little contact with me... I don't care much } \\
\text { about the my relationship with them }\end{array}$ \\
\hline \multirow{5}{*}{$\begin{array}{l}\text { I\#08's utility of life } \\
\text { (I used to feel happy } \\
\text { when my child } \\
\text { lived with me, } \\
\text { but now I feel flat) }\end{array}$} & Stimulation & Physical strength, energy & $\begin{array}{l}\text { Sometimes I feel a little tired, but the overall situation is OK. } \\
\text { When I am tired, I rest }\end{array}$ \\
\hline & $\begin{array}{l}\text { Internal } \\
\text { Comfortable }\end{array}$ & Somatic comfort & $\begin{array}{l}\text { I have plenty of time to rest. I rest when I want to... } \\
\text { I exercise and occasionally go out with friends }\end{array}$ \\
\hline & $\begin{array}{l}\text { External } \\
\text { Comfortable }\end{array}$ & $\begin{array}{l}\text { Living conditions } \\
\text { and environments }\end{array}$ & $\begin{array}{l}\text { Now I live in the house I bought. The space of the house is small, } \\
\text { but the sanitary conditions are OK. The amenities around } \\
\text { my house are very good }\end{array}$ \\
\hline & Status & Occupation and income & $\begin{array}{l}\text { I started to do building materials business in } 2003 \text {, and my income } \\
\text { is OK. I also bought my own house in Beijing... But now the } \\
\text { national policy has a strong pressure on the building materials } \\
\text { industry, and the good development environment is } \\
\text { coming to an end. I m ready to change my profession }\end{array}$ \\
\hline & $\begin{array}{l}\text { Behavioral } \\
\text { confirmation }\end{array}$ & $\begin{array}{l}\text { Do reasonable } \\
\text { and valuable things }\end{array}$ & $\begin{array}{l}\text { I live alone in Beijing now, because Beijing is the city that responds } \\
\text { most quickly to current events and policies, and life here is also very } \\
\text { convenient... My child is studying in another place and Beijing is a } \\
\text { transfer station for me. In the future, I will live in the city where my } \\
\text { child live. And I will buy houses for myself and my child in that city }\end{array}$ \\
\hline
\end{tabular}




\section{Continued}

\begin{tabular}{|c|c|c|c|}
\hline & Affection & $\begin{array}{l}\text { Interpersonal } \\
\text { communication and } \\
\text { emotions }\end{array}$ & $\begin{array}{l}\text { My relationship with my parents is } O K, \text { but not very good with } \\
\text { my spouse. I have a good relationship with my friends... } \\
\text { I live in a place where I don't have many neighbors and } \\
\text { I seldom participate in community activities }\end{array}$ \\
\hline & $\begin{array}{c}\text { Physical } \\
\text { well-being }\end{array}$ & Health conditions & $\begin{array}{l}\text { I worked very hard some years ago, sometimes I don't eat in time, } \\
\text { which affected my health, but now my health is OK }\end{array}$ \\
\hline & $\begin{array}{c}\text { Social } \\
\text { well-being }\end{array}$ & Social relations & $\begin{array}{l}\text { I live alone in Beijing now... Now I work and live by myself, } \\
\text { my family don't live together, but we also have contacts }\end{array}$ \\
\hline \multirow{8}{*}{$\begin{array}{l}\text { I\#11's utility of life } \\
\text { (I am very satisfied } \\
\text { with my living } \\
\text { conditions and my work) }\end{array}$} & Stimulation & Physical strength, energy & $\begin{array}{l}\text { I can keep up with my energy and physical strength. My work is } \\
\text { always under pressure, but I can accept it. I don't feel very tired }\end{array}$ \\
\hline & $\begin{array}{c}\text { Internal } \\
\text { Comfortable }\end{array}$ & Somatic comfort & $\begin{array}{l}\text { I feel a little fatigued when I work overtime, } \\
\text { but generally I don't have pain and other sensation }\end{array}$ \\
\hline & $\begin{array}{c}\text { External } \\
\text { Comfortable }\end{array}$ & $\begin{array}{l}\text { Living conditions } \\
\text { and environments }\end{array}$ & $\begin{array}{l}\text { The space of the house is small when we rented a house a } \\
\text { few years ago. Now we live in the house I bought, and } \\
\text { the space is larger and the sanitary conditions are better. } \\
\text { Now we live in a very convenient place }\end{array}$ \\
\hline & Status & Occupation and income & $\begin{array}{l}\text { I have been engaged in research and development in the Internet } \\
\text { software industry, and I am very satisfied with my current income }\end{array}$ \\
\hline & $\begin{array}{l}\text { Behavioral } \\
\text { confirmation }\end{array}$ & Do right things & $\begin{array}{l}\text { My life in Beijing is similar to what I expected. The house problem } \\
\text { has been resolved and we have bought a house... I am still worried } \\
\text { about whether my child can take the college entrance examination in } \\
\text { Beijing in the future, because she don't have local hukou. However, } \\
\text { I still have hope to acquire Beijing hukou (household registration } \\
\text { books), and I have applied for jifen luohu (points-based household } \\
\text { registration system)... Although my parents regard that Beijing is } \\
\text { far away from our hometown, they also support us to stay in Beijing }\end{array}$ \\
\hline & Affection & $\begin{array}{l}\text { Interpersonal } \\
\text { communication } \\
\text { and emotions }\end{array}$ & $\begin{array}{l}\text { Now family members live together every day, } \\
\text { caring and loving each other }\end{array}$ \\
\hline & $\begin{array}{c}\text { Physical } \\
\text { well-being }\end{array}$ & Health conditions & I often exercise and my health is $\mathrm{OK}$ \\
\hline & $\begin{array}{c}\text { Social } \\
\text { well-being }\end{array}$ & Social relations & $\begin{array}{l}\text { I keep normal interpersonal relationships with people around me. } \\
\text { I have a good relationship with my family and I feel happy }\end{array}$ \\
\hline
\end{tabular}

Note: The raw data is from the interview of respondent I\#01, I\#08 and I\#11, respectively. Source: Authors' arrangement.

physical well-being and social well-being, respondent I\#01's actual utility of life is low. In the same way, it is found that respondent I\#11' actual utility of life is high because his physical well-being and social well-being are both produced at a high level. While respondent I\#08' actual utility of life is at a medium level and the main reason is that her social well-being is produced at a relatively low level. Although respondent I\#08' instrumental goals of status and behavioral confirmation are both achieved at a high level, the instrumental goal of affection is achieved at a low level mainly due to a bad relationship with her spouse, which reduces the overall level of social well-being.

\subsubsection{Extending the Theoretical Lens}

In the process of coding, it was found that some of the raw data could not be explained well by the existing theoretical lens, which implied that new theories 
were required to extend the existing theoretical lens (Goh et al., 2013). Specifically, the respondents all reported the conditions that people at various life course stages should (need to) have for living in Beijing rather than the current conditions they had. As shown in Table 4, through thematic coding, "the conditions that people should have" can be classified into corresponding instrumental goals in SPF theory (Lindenberg \& Frey, 1993; Ormel et al., 1997). According to SPF theory, the process that people get the conditions is the process that they achieve the instrumental goals, which will eventually produce "the utility of life that people should obtain" as the utility of life is produced by multi-level life goals through social production functions (Ormel et al., 1997). Inspired by Naugarten \& Hagestad's (1976) view of normative timetable, which refers to the society has expectations for the appropriate age for the occurrence of major life course events such as attending school, having jobs, getting married, raising children, and retirement, we employ the term "normative utility" to denote "the utility of life that people should obtain". "Normative utility" refers to society's expectations for the living utility of people in mega-cities in various life course stages and implies that a specific set of "necessary conditions" required for people to live in mega-cities. Therefore, based on the existing theoretical lens of life utility, the concept of "normative utility" is added as another theoretical perspective. In other words, the original theoretical lens has been extended.

Note here that life course stage is a key concern in migrants' choice of residence (Plane \& Heins, 2003). According to the statements of respondents, there are differences in the conditions that people at various life course stage should have for living in Beijing. As shown in Table 4, based on the analysis of these living conditions, the life course of a person in Beijing corresponds to four stages: 1) adolescence and youth, which refers to less than 30 years old; 2) late youth, which refers to 30 to 40 years old; 3 ) middle of life, which refers to 40 to 60 years old; and 4) old age, which refers to above 60 years old. Base on the thematic coding, the specific entities of the "normative utility" in each life course stage are summarized in Table 5. The entities of the "normative utility" correspond to the two universal needs of people for physical well-being and social well-being in SPF theory. It should be noted here that utility of life is a person's subjective sense, but "normative utility" has an objective meaning, and the latter essentially refers to the standard pre-requisite of living conditions that people need to meet for living in mega-cities. As Naugarten \& Hagestad (1976) argue, at every life course stage, if people's time of major life course events deviate from the "normative timetable", there may be a series of undesirable social consequences and people would be "punished and sanctioned" by the society. Correspondingly, at every life course stage of floating people in mega-cities, if the "normative utility" is not obtained, the floating people will feel the pressure from other people. These "necessary conditions" corresponding to each life course stage are internalized into the consciousness of the floating people, which is not only the pressure but also the driving force of their urban lives. 
Table 4. The thematic coding of the concept of "normative utility".

\begin{tabular}{|c|c|}
\hline Theoretical lens & Snippet of raw data and theoretical unit labeling \\
\hline \multirow{2}{*}{$\begin{array}{l}\text { (Adolescence and youth) } \\
\text { "normative utility" } \\
\text { produced by Social } \\
\text { production functions }\end{array}$} & $\begin{array}{l}\text { I\#18 Young people before the age of } 30 \text { (adolescence and youth) } \\
\text { need to work hard and be positive. Nowadays, the living standard } \\
\text { has been improved, and the living requirements in Beijing have } \\
\text { naturally increased, including stable work (status) and stable } \\
\text { residence (external comfort). If I get married and have children, } \\
\text { I can afford to support them and provide them for school } \\
\text { (behavioral confirmation) }\end{array}$ \\
\hline & $\begin{array}{l}\text { I\#13 In the } 20 \text { 's (adolescence and youth), people in Beijing should } \\
\text { have stable income and housing (status, external comfort), } \\
\text { If they live in a rented house, the rent should be cheap. Moreover, } \\
\text { children can go to school normally (behavioral confirmation) }\end{array}$ \\
\hline \multirow[t]{2}{*}{$\begin{array}{l}\text { (Late youth) } \\
\text { "normative utility" } \\
\text { produced by Social } \\
\text { production functions }\end{array}$} & $\begin{array}{l}\text { I\#27 In the 30's (late youth), people in Beijing should have better } \\
\text { conditions, and the food, housing and transportation are not } \\
\text { problems (internal comfort, external comfort). At that time, they } \\
\text { will pay attention to the meaning of work (behavior confirmation) } \\
\text { and the environment (external comfort). Moreover, children } \\
\text { should go to school, and the descendants should do more to support } \\
\text { their parents because parents are old (behavior confirmation), } \\
\text { so life should be happy and warm (affection) }\end{array}$ \\
\hline & $\begin{array}{l}\text { I\#16 In the 30's and the } 400^{\circ} \text { (late youth), people in Beijing should } \\
\text { have their own house (external comfort), stable job (status), } \\
\text { better economic abilities than their } 20 \text { s (status), and can afford } \\
\text { the whole family's cost (behavior confirmation). } \\
\text { And children should go to school normally (behavior confirmation) }\end{array}$ \\
\hline \multirow{2}{*}{$\begin{array}{l}\text { (Middle of life) } \\
\text { "normative utility" } \\
\text { produced by Social } \\
\text { production functions }\end{array}$} & $\begin{array}{l}\text { I\#08 In the } 40 \text { 's (middle of life), people in Beijing should have stable } \\
\text { housing (external comfort) and considerable income (status). } \\
\text { And at that time, people should take more responsibility, and } \\
\text { spend more time with the elderly (behavior confirmation). } \\
\text { And more companionship should be shared with relatives (affection) }\end{array}$ \\
\hline & $\begin{array}{l}\text { I\#22 Middle-aged people between } 40 \text { and } 60 \text { in Beijing } \\
\text { (middle of life) should have relatively stable material conditions } \\
\text { such as housing and cars (status, external comfort) } \\
\text { and take good care of the children and the elderly } \\
\text { (behavior confirmation), moreover, they should } \\
\text { accomplish their own businesses (status, behavior confirmation) }\end{array}$ \\
\hline \multirow{2}{*}{$\begin{array}{l}\text { (Old age) } \\
\text { "normative utility" } \\
\text { produced by Social } \\
\text { production functions }\end{array}$} & $\begin{array}{l}\text { I\#03 People after } 60 \text { (old age) in Beijing should have a healthy } \\
\text { body and mind (stimulation), the ability to live a peaceful life } \\
\text { (status, external comfort), adequate pension and insurance (status), } \\
\text { and harmonious family life (affection) }\end{array}$ \\
\hline & $\begin{array}{l}\text { I\#14 I don't think much about life in Beijing when I am over } 60 \\
\text { (old age), but at least I should be able to support my old age well } \\
\text { (status). Besides the guarantee of living and housing } \\
\text { (external comfort), there should also be good medical care } \\
\text { and insurance (status) }\end{array}$ \\
\hline
\end{tabular}

Note: 1) Values in parentheses are life course stages and/or theoretical units. 2) It should be noted that each respondent's transcript only involves several of the six instrumental goals in SPF theory. The reason is that each respondent pays more attention to some of these goals, which confirms that the instrumental goals can be replaced with each other to some extent according to the goals' cost of achievement (Lindenberg \& Frey, 1993). Furthermore, it can be inferred from each transcript that those instrumental goals not mentioned by the respondent should be achieved at least at an acceptable level. Source: Authors' arrangement. 
Table 5. "Normative utility" in mega-cities corresponding to each life course stage.

\begin{tabular}{ll}
\hline Life course stages & Specific entities \\
\hline $\begin{array}{l}\text { Adolescence and youth } \\
\text { (less than } 30 \text { years old) }\end{array}$ & $\begin{array}{l}\text { Physical well-being: stable residence } \\
\text { Social well-being: jobs with good development trends, } \\
\text { good education for children }\end{array}$ \\
\hline Late youth (30 to 40 years old) & $\begin{array}{l}\text { Physical well-being: own house } \\
\text { Social well-being: higher-level jobs, good education } \\
\text { for children, a happy family }\end{array}$ \\
\hline Middle of life (40 to 60 years old) & $\begin{array}{l}\text { Physical well-being: excellent medical security } \\
\text { Social well-being: stable jobs, good economic conditions, } \\
\text { a happy family }\end{array}$ \\
\hline Old age (above 60 years old) & $\begin{array}{l}\text { Physical well-being: excellent medical security } \\
\text { Social well-being: steady economic conditions, } \\
\text { a happy family }\end{array}$ \\
\hline
\end{tabular}

Source: Authors' arrangement.

\subsection{Selective Coding}

\subsubsection{Determining the Typical Relationship Structure}

The selective coding is followed by the thematic coding. According to the steps of selective coding proposed by Goh et al. (2013), first, by analyzing the relationship between the main categories (definition and types of EFL, life course stage, actual utility of life) and the theoretical lens (utility of life, normative utility), we have made it clear that the "core category" is "the formation mechanism of EFL".

Then, the typical relationship structure of the core category with the main categories, theoretical lens, and other categories are determined in the form of "story line", that is, a person's expectations for the future life is formed based on the comparison between the actual utility of life and "normative utility" in the specific life course stage. The results are shown in Table 6.

\subsubsection{Developing the Theoretical Model}

Based on the above typical relationship structure, this article developed a theoretical model of EFL for floating people in mega-cities. After the theoretical model was established, each of the three researchers compared pairwise with the interview data, theoretical lens and theoretical model repeatedly to confirm that they are consistent. Furthermore, each researcher used the 9 copies of transcripts of interviews from respondents I\#31 - I\#39 to check the theoretical saturation, and the results showed that the new data had little new influence or change on the theoretical model, which indicated that the theoretical saturation had been reached.

As shown in Figure 2, in each course stage of life in mega-cities, the society has expectations for the specific life goals that people should achieve. Therefore, through the calculation of social production functions (Lindenberg \& Frey, 1993) (the thin arrows in the middle of Figure 2 denote functional relationships), 
Table 6. Selective coding.

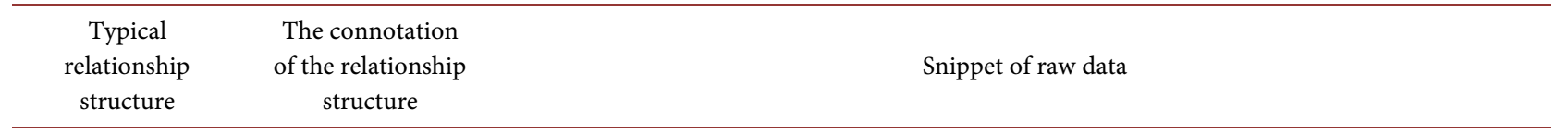

$\begin{array}{ll}\text { Actual utility of } & \begin{array}{l}\text { The individual is } \\ \text { in a specific life }\end{array} \\ \text { life corresponds } & \begin{array}{l}\text { course stage, and } \\ \text { he/she gets the }\end{array} \\ \text { to life } & \begin{array}{l}\text { current actual } \\ \text { course stage }\end{array} \\ & \text { utility of life }\end{array}$
corresponds to life course stages
I\#05 I have no sense of happiness in Beijing, and I come to Beijing just for earning money. I feel that I have been living at the bottom of the society (Respondent I\#05, who is now 37 years old and is in the life course stage of late youth, gets his actual utility of life)

I\#14 Now I can score 60 to 70 points on the happiness of living in Beijing, and I feel that I am not as happy as living with my parents (Respondent I\#14, who is now 24 years old and is in the life course stage of adolescence and youth, gets her actual utility of life)

I\#04 If people at the stage of 30 to 40 years old live in Beijing, their income should be above average and their job should be as stable as possible. If people don't like their jobs, they can choose the industry which they want to work in. People aged 30 to 40 should be

At each specific life course stage, the society has corresponding expectations for utility of life toward people who live in mega-cities married with houses and cars. Moreover, the family often travels, and the children can go to school normally in Beijing (Respondent I\#04 believes that the main goals that people who live in Beijing in the life course stage of late youth should achieve, and the realization of these goals will ultimately leads to the utility of life expected by the society)

I\#15 People living in Beijing between the aged 20 and 30 should have stable accommodation, and be able to afford their own expenses. If they don't have a family, they should have a certain friendship. After getting married, people should have their own houses, be able to afford the family's expenses, and make sure that their children can go to school normally. Also, when people get sick, the company will have a certain amount of reimbursements (Respondent I\#15 thinks that the main goals should be achieved by the people who live in Beijing in the life course stage of adolescence and youth, and the realization of these goals will ultimately leads to the utility of life expected by the society)

I\#20 \& I\#21 We have stayed in Beijing for a long time and we don't have any feeling or sense of happiness. Anyway, we need to work hard to make money. There is no way to do it and it $s$ all for the next generation. We can't afford a house in Beijing and my children can't take the college entrance examination here. These problems can't be solved. When my children's major problems are solved, we will leave Beijing and return to our rural home (Respondent I\#20 and I\#21 compare their current actual utility of life with the "normative utility" and hold the expectations for the future life, which is "to have decided to live in mega-cities for a period of time and then move to another place")

In the current life course stage, the person perceives

EFL is formed the result of the

\section{based the} comparison comparison between a between his/her actual utility of life and the person's actual "normative utility", utility of life and "normative utility" in his/her specific so that the person can make a pre-judgment or estimation of living conditions in the future
I\#09 People aged 30 to 40 who live in Beijing should have a stable source of income with their own houses, and give their children a fair opportunity of education. There is still a gap between my present life and the ideal state, but I am still working hard to achieve it. The happiness of my life in Beijing in the past few years is relatively high, but it has declined a little in recent years. I intend to continue working in Beijing for a while, because I really want to work in Beijing when I was a child and I will never forget my first thought. However, considering the future environment of Beijing, if the efforts of easing the non-core functions are intensified, I may not be able to live in Beijing and I will choose to move to other cities for development. The clothing industry I am engaged in is a labor-intensive industry, which is the target of easing non-core functions by the Beijing Municipal Government (Respondent I\#09 compares his current actual utility of life with the "normative utility" and holds the expectations for the future life, which is "to live in mega-cities for a while and then make a decision on where to live in the future")

I\#22 I am very satisfied with the current work and living conditions and the happiness of living in Beijing is getting higher and higher... I want to work in Beijing and do some businesses in the pharmaceutical industry in the future. However, I will not go back to my hometown. (Respondent I\#22 compares his current actual utility of life with the "normative utility" and holds the expectations for the future life, which is "to stay in mega-cities in the future")

Note: Values in parentheses are illustrations of the raw data. Source: Authors' arrangement. 


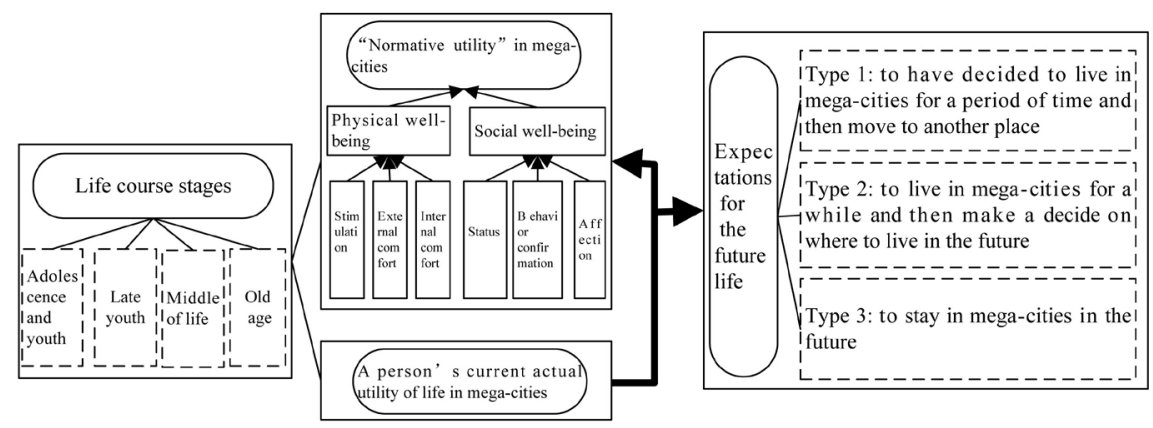

Figure 2. Theoretical model of EFL of floating people in mega-cities of China. Source: Authors' drawing.

the achievement of these life goals eventually produce the utility of life that people deserve, i.e., the "normative utility".

A person in mega-cities perceives his/her current actual utility of life, and he/she will compare it with the "normative utility" (the thick arrow on the left in Figure 2 denotes the comparison between the two).The individual makes a pre-judgment or estimation of living conditions in the future based on the result of this comparison. In other words, the expectations for the future life is formed (the thick arrow on the right in Figure 2 denotes that the comparison will produce results). The core concerns of this pre-judged future living conditions is whether the person expects to live in mega-cities. The specific types of FEL (shown in the dotted box on the right part of Figure 2) are as follows: 1) in the first type, if the actual utility of life is obviously ${ }^{6}$ less than the "normative utility", the EFL of floating people is to have decided to live in mega-cities for a period of time and then move to another place; 2 ) in the second type, if the actual utility of life is not much less than the "normative utility", or the former is close to the latter, the EFL of floating people is to live in mega-cities for a while and then make a decision on where to live in the future; 3 ) in the third type, if the actual utility of life is roughly equal to or greater than the "normative utility", the EFL of floating people is to stay in mega-cities in the future.

\section{Discussions}

Among the 17 rural-urban migrants interviewed, 11 persons' EFL is all the first type. In terms of destination selection after moving out of Beijing, 8 persons would return to their rural hometowns, one person (respondent I\#08) would move to another city, and a couple (respondent I\#12 and I\#13) would go to their hometown county. This is different from Li's (2003) findings in two aspects: 1) the respondents in our sample show diversity in destination selection, not all of them would go back to their rural hometowns; 2) not all of these rural-urban migrants would leave Beijing when they are old, but some have their own time plans. For instance, when her child starts working in a city, respondent I\#08 plans to move to that city. Another example, respondent I\#12 and I\#13 plan to ${ }^{6}$ The "obviously" here is judged based on the narratives of the respondent and the narratives such as "poor too far" and "very far away" are considered to be "obviously". 
leave Beijing in five or six years. One possible explanation is the target-earnings motivation, that is, migrants leave when they have met their savings goals in the city (Yang, 2006; Vadean \& Piracha, 2009). The reason why our respondents would return to their rural hometowns is not only that they cannot afford the high costs of permanent settlement in mega-cities, but also that the conditions of rural life are irresistibly attractive to them. As far as they are concerned, there are relatives, housing property, contracted land and familiar environment in the rural homes. Meanwhile, another 5 rural-urban migrants' EFL is all the second type. These individuals all have accumulated considerable earnings in Beijing due to their successful businesses or professional skills, which provides an economic basis for them to settle permanently in Beijing in the future. In addition, respondent I\#19's EFL is the third type. As shown in Table 2, the actual utility of life of respondent I\#19 is greater than the "normative utility", which corroborates the formation mechanism of EFL.

Notable differing from most rural-urban migrants, among the 12 educated migrants with a college degree or above interviewed, except that the EFL of respondent I\#26 and I\#28 is both the first type, the EFL of other 10 people is either the second or the third type. As all the educated migrants claimed that they desired to remain in Beijing in the future, but only a few with sufficient income and social capital, like respondent I\#11, I\#18 and I\#22, would achieve this goal. For the individuals with the first and the second types of EFL, the inability to purchase local housing and/or enrol their children in local schools are two major obstacles that they are not sure whether to settle in Beijing in the future. In particular, the latter forces many migrants to move out of Beijing. In terms of destination selection after moving out of Beijing, respondent I\#26 would go back to his hometown when he retires, while respondent I\#28 would choose a city where her children can go to high-quality schools.

Besides, respondent I\#25 is a city-origin migrant with a senior high school education, he comes from Tangshan and has lived in Beijing for 5 years. He lives alone in Beijing, leaving his wife and son to live in Tangshan. His EFL is the second type and his biggest difficulty at present is that his income can't afford to buy a housing property in Beijing.

The results show that the concept of life course is very vital to understand the formation mechanism of EFL. In his/her specific life course stage, each respondent in the sample has to face some life course events, mainly including purchasing a housing property, career advancing, family formation, enrolling child(ren) and retirement. If he/she can achieve the goals or handle these events smoothly, his/her actual utility of life will be improved, thus increasing the possibility of living in Beijing for a long time. On the contrary, it is a disadvantage to remain in Beijing.

Contradicting the statement given by De Jong (2000), that the expectations for the future life is formed by evaluating the chances for future attainment of valued goals (e.g., finding a job or advancing one's career) in the home community in comparison to the destination community rather than the same community, 
the expectations in this paper is formed by comparing the actual utility of life with the "normative utility" in the current community. Note that this article focuses on secondary migration, whereas De Jong (2000) was aimed on primary migration, hence the contradiction.

In addition, it is worth noting that based on neoclassical framework in which utility is typically represented by income streams, the conceptualization of utility in this article is expanded. In our study, a person's utility comes not only from pecuniary factors but also from non-pecuniary factors, e.g., the relationship with others. Furthermore, the comparison between a person's actual utility of life and the "normative utility" is consistent with the view that people are used to interpersonal comparison, and the result affects their feelings of happiness. This has been corroborated by a large amount of empirical evidences from econometrics, experimental economics, social psychology and brain science (Stark, 2017).

\section{Conclusion}

In recent years, along with the vast economic development, China's mega-cities attract a great number of migrants. These migrants without local hukou, i.e., floating people, are always faced with the uncertainties of either remaining or leaving from these cities. Expectations for the future life (EFL) of floating people in China's mega-cities has always been a neglected topic of research. We argue that EFL is a person's pre-judgment or estimation of living conditions in the future based on his/her perception of current human well-being or utility of life and its main concern is whether he/she expects to live in the mega-city in the future. Based on the social production functions (SPF) theory, three types of EFL for floating population are identified by using data collected from in-depth interviews with 30 Beijing's migrants. The first and the third types suggest that migrants surely tend to leave and remain in the mega-city respectively, whereas the second type indicates that migrants depend on the future living conditions to make decisions on whether to remain in the mega-city.

This paper reveals that the EFL of floating population is formed by comparing their current actual utility of life with the "normative utility" in the specific life course stage, which is the life utility that people should have in their specific life course stage expected by the society. Finally, these findings are checked out that the theoretical saturation has been reached by applying another 9 copies of transcripts of interviewees.

Turning to the implications of this research, given that the EFL of many rural-urban migrants is to return to their rural hometowns, the local government should formulate some effective policies to protect the interests of these returners, such as farmland and contracted land. Additionally, the EFL for many educated migrants' outmigration decisions can be translated to the loss in urban and economic developments for China's mega-cities in the long term. In order to avoid these long-term development losses, some reformations on the current urban welfare systems which may change individuals' EFL in the direction of keeping them in Beijing should be considered to provide educated migrants wider 
opportunities and easier education access for their children to settle down in mega-cities.

Several notes of caution, however, have to be made. First, as they live for a longer time in mega-cities, migrants' EFL may change, but this paper does not explore its law. Second, each mega-city has its unique characteristics in many aspects, such as geographical location, industrial type and population structure. Whether the conclusions drawn from the study of Beijing are applicable to other mega-cities remains to be tested with actual data. An ambitious data collection effort, which, for the whole life course stages of individuals and/or for other mega-cities, is necessary to provide a more comprehensive view of EFL of floating people.

\section{Acknowledgements}

We would like to thank Professor Wang Kanliang from Renmin University of China, Professor Wang Lin from Tianjin Normal University and Dr. Yang Yafen from Hangzhou Dianzi University for their valuable suggestions. Of course, the authors are responsible for the viewpoints in this paper.

\section{Funding}

This study was supported by the National Social Science Foundation of China [17CGL075].

\section{Conflicts of Interest}

The authors declare no conflicts of interest regarding the publication of this paper.

\section{References}

Astuti, L. T. M., Tjiptoherijanto, P., Haeruman, H., \& Koestoer, R. (2015). Model of Sustainable Wellbeing on Decent House Study Case of Bekasi City, West Java, Indonesia. Procedia Environmental Sciences, 28, 370-379. https://doi.org/10.1016/j.proenv.2015.07.046

Blejer, M. I., \& Goldberg, I. (1980). Return Migration: Expectations versus Reality. A Case Study of Western Immigrants to Israel. Research in Population Economics, 2, 433-449.

Boneva, B. S., \& Frieze, I. H. (2001). Toward a Concept of a Migrant Personality. Journal of Social Issues, 57, 477-491. https://doi.org/10.1111/0022-4537.00224

Borjas, G. J., \& Bratsberg, B. (1996). Who Leaves? The Outmigration of the Foreign-Born. The Review of Economics and Statistics, 78, 165-176. https://doi.org/10.2307/2109856

Cai, R. H., Neli, E., Michael, O., \& Shuaizhang, F. (2014). International Migration Desires Related to Subjective Well-Being. IZA Journal of Migration, 3, Article number: 8. https://doi.org/10.1186/2193-9039-3-8

Carr, A. J., Gibson, B., \& Robinson, P. G. (2001). Measuring Quality of Life: Is Quality of Life Determined by Expectations or Experience? The British Medical Journal, 322, 1240-1243. https://doi.org/10.1136/bmj.322.7296.1240

Castells, M. (1996). The Rise of the Network City. Oxford: Blackwell. 
Chindarkar, N. (2014). Is Subjective Well-Being of Concern to Potential Migrants from Latin America? Social Indicators Research, 115, 159-182. https://doi.org/10.1007/s11205-012-0213-7

Cummins, R. A. (2000). Objective and Subjective Quality of Life: An Interactive Model. Social Indicators Research, 52, 55-72. https://doi.org/10.1023/A:1007027822521

De Jong, G. F., Chamratrithirong, A., \& Tran, Q.-G. (2002). For Better, for Worse: Life Satisfaction Consequences of Migration. International Migration Review, 36, 838-863. https://doi.org/10.1111/j.1747-7379.2002.tb00106.x

De Jong, G. F. (2000). Expectations, Gender, and Norms in Migration Decision-Making. Population Studies, 54, 307-319. https://doi.org/10.1080/713779089

Ferrans, C. E. (1996). Development of a Conceptual Model of Quality of Life. Scholarly Inquiry for Nursing Practice: An International Journal, 10, 293-304.

Furuseth, O. J., \& Walcott, W. A. (1990). Defining Quality of Life in North Carolina. The Social Science Journal, 27, 75-93. https://doi.org/10.1016/0362-3319(90)90011-8

Gao, W. S., \& Smyth, R. (2010). Future Income Expectations and Life Satisfaction of China's Rural Urban Migrant Workers: An Empirical Study on the Migrant Workers in Shanghai and Other Cities. Journal of Yunnan University of Finance and Economics, No. 6, 21-33.

Ge, J., \& Hokao, K. (2006). Research on Residential Lifestyles in Japanese Cities from the Viewpoints of Residential Preference, Residential Choice and Residential Satisfaction. Landscape and Urban Planning, 78, 165-178.

https://doi.org/10.1016/j.landurbplan.2005.07.004

Goh, J.C.-L., Pan, S. L., \& Zuo, M. Y. (2013). Developing the Agile IS Development Practices in Large-Scale IT Projects: The Trust-Mediated Organizational Controls and IT Project Team Capabilities Perspectives. Journal of the Association for Information Systems, 14, 722-756. https://doi.org/10.17705/1jais.00348

Graham, C., \& Markowitz, J. (2011). Aspirations and Happiness of Potential Latin American Immigrants. Journal of Social Research and Policy, 2, 9-25.

He, X. F. (2014). China's Road of Urbanization. Beijing: Oriental Press.

Heaton, T. B., Clifford, W. B., \& Fuguitt, G. V. (1981). Temporary Shifts in the Determinants of Young and Elderly Migration in Nonmetropolitan Areas. Social Forces, 60, 41-60. https://doi.org/10.2307/2577931

Hoppe, A., \& Fujishiro, K. (2015). Anticipated Job Benefits, Career Aspiration, and Generalized Self-Efficacy as Predictors for Migration Decision-Making. International Journal of Intercultural Relations, 47, 13-27. https://doi.org/10.1016/j.ijintrel.2015.03.025

Hu, F., Xu, Z. Y., \& Chen, Y. Y. (2011). Circular Migration, or Permanent Stay? Evidence from China's Rural-Urban Migration. China Economic Review, 22, 64-74. https://doi.org/10.1016/j.chieco.2010.09.007

Ivlevs, A. (2015). Happy Moves? Assessing the Link between Life Satisfaction and Emigration Intentions. Kyklos, 68, 335-356. https://doi.org/10.1111/kykl.12086

Jasinskaja-Lahti, I., \& Yijälä, A. (2011). The Model of Pre-Acculturative Stress-A Pre-Migration Study of Potential Migrants from Russia to Finland. International Journal of Intercultural Relations, 35, 499-510. https://doi.org/10.1016/j.ijintrel.2010.11.003

Kleiner, M. M. (1984). Metropolitan Migration and Labor Market Changes by Industry. The Annals of Regional Science, 18, 11-24. https://doi.org/10.1007/BF01287371

Li, L. M., Li, S.-M., \& Chen, Y. F. (2010). Better City, Better Life, but for Whom?: The 
Hukou and Resident Card System and the Consequential Citizenship Stratification in Shanghai. City, Culture and Society, 1, 145-154.

https://doi.org/10.1016/j.ccs.2010.09.003

Li, Q. (2003). An Analysis of Push and Pull Factors in the Migration of Rural Workers in China. Social Sciences in China, 1, 125-136.

Li, X. Z. (2017). The Structural Characteristics and Countermeasures of Floating Population in Beijing. Social Sciences of Beijing, 11, 4-16.

Lindenberg, S., \& Frey, B. S. (1993). Alternatives, Frames, Relative Prices: A Broader View of Rational Choice Theory. Acta Sociologica, 36, 191-205. https://doi.org/10.1177/000169939303600304

Liu, B.-C. (1975). Differential Net Migration Rates and the Quality of Life. Review of Economics and Statistics, 57, 329-337. https://doi.org/10.2307/1923917

Mankiw, N. G. (2012). Economic Principles (6th Edition, Microeconomics Volume). X. M. Liang, \& L. Liang (Trans.). Beijing: Peking University Press.

Moons, P., Budts, W., \& De Geest, S. (2006). Critique on the Conceptualisation of Quality of Life: A Review and Evaluation of Different Conceptual Approaches. International Journal of Nursing Studies, 43, 891-901. https://doi.org/10.1016/j.ijnurstu.2006.03.015

Morrill, R., Downing, J., \& Leon, W. (1986). Attribute Preferences and the Non-Metropolitan Migration Decision. The Annals of Regional Science, 20, 33-53.

https://doi.org/10.1007/BF01283622

Morris, E. A. (2019). Do Cities or Suburbs Offer Higher Quality of Life? Intrametropolitan Location, Activity Patterns, Access, and Subjective Well-Being. Cities, 89, 228-242. https://doi.org/10.1016/j.cities.2019.02.012

Naugarten, B. L., \& Hagestad, G. O. (1976). Age and the Life Course. In H. B. Robert, \& S. Ethel (eds.), Handbook of Aging and the Social Sciences (pp. 35-55). New York: Van Nostrand Reinhold.

Ormel, J., Lindenberg, S., Steverink, N., \& Michael, V. (1997). Quality of Life and Social Production Functions: A Framework for Understanding Health Effects. Social Science \& Medicine, 45, 1051-1063. https://doi.org/10.1016/S0277-9536(97)00032-4

Otrachshenko, V., \& Popova, O. (2014). Life (Dis)Satisfaction and the Intention to Migrate: Evidence from Central and Eastern Europe. Journal of Socio-Economics, 48, 40-49. https://doi.org/10.1016/j.socec.2013.09.008

Pan, G., Pan, S. L., \& Lim, C.-Y. (2015). Examining How Firms Leverage IT to Achieve Firm Productivity: RBV and Dynamic Capabilities Perspectives. Information \& Management, 52, 401-412. https://doi.org/10.1016/j.im.2015.01.001

Plane D. A., Henrie, C. J., \& Perry, M. J. (2005). Migration up and down the Urban Hierarchy and across the Life Course. Proceedings of the National Academy of Science, 102, 15313-15318. https://doi.org/10.1073/pnas.0507312102

Plane, D. A., \& Heins, F. (2003). Age Articulation of U.S. Inter-Metropolitan Migration Flows. The Annals of Regional Science, 37, 107-130.

https://doi.org/10.1007/s001680200114

Porell, F. W. (1982). Intermetropolitan Migration and Quality of Life. Journal of Regional Science, 22, 137-158. https://doi.org/10.1111/j.1467-9787.1982.tb00741.x

Siggelkow, N. (2007). Persuasion with Case Studies. The Academy of Management Journal, 50, 20-24. https://doi.org/10.5465/amj.2007.24160882

Speare, A., Korbin, J. F., \& Kingkade, W. (1982). The Influence of Socioeconomic Bonds and Satisfaction on Interstate Migration. Social Forces, 61, 551-574.

https://doi.org/10.2307/2578241 
Stark, O. (2017). Migration when Social Preferences are Ordinal: Steady State Population Distribution, and Social Welfare. Economica, 84, 1-33. https://doi.org/10.1111/ecca.12245

Stockdale, A. (2016). Contemporary and "Messy" Rural In-Migration Processes: Comparing Counter-Urban and Lateral Rural Migration. Population, Space and Place, 22, 599-616. https://doi.org/10.1002/psp.1947

Stockdale, A., Marsaili, M., \& Lorna, P. (2013). Connected Life Courses: Influences on and Experiences of "Midlife" In-Migration to Rural Areas. Population, Space and Place, 19, 239-257. https://doi.org/10.1002/psp.1709

Tabor, A. S., \& Milfont, T. L. (2011). Migration Change Model: Exploring the Process of Migration on a Psychological Level. International Journal of Intercultural Relations, 35, 818-832. https://doi.org/10.1016/j.ijintrel.2010.11.013

Todaro, M. P. (1976). Internal Migration in Developing Countries: A Review of Theory, Evidence, Methodology and Research Priorities (pp. 1-30). Geneva: International Labor Office.

Vadean, F., \& Piracha, M. (2009). Circular Migration or Permanent Return: What Determines Different Forms of Migration? (pp. 1-30). IZA Discussion Papers, No. 4287.

Van Dalen, H. P., \& Henkens, K. (2012). Explaining Low International Labour Mobility: The Role of Networks, Personality, and Perceived Labour Market Opportunities. Population, Space and Place, 18, 31-44. https://doi.org/10.1002/psp.642

Van Dalen, H. P., \& Henkens, K. (2013). Explaining Emigration Intentions and Behaviour in the Netherlands, 2005-10. Population Studies, 67, 225-241.

https://doi.org/10.1080/00324728.2012.725135

Veenhoven, R. (2017). Greater Happiness for a Greater Number: Did the Promise of Enlightenment Come True? Social Indicators Research, 130, 9-25. https://doi.org/10.1007/s11205-015-1128-x

Wallace, M., \& Wu, Q. (M.). (2018). Immigration and the Quality of Life in U.S. Metropolitan areas. The Social Science Journal, 56, 443-457. https://doi.org/10.1016/j.soscij.2018.09.016

Wang, Z., Pan, S. L., Quyang, T. H., \& Chou, T. C. (2014). Achieving IT-Enabled Enterprise Agility in China: An IT Organizational Identity Perspective. IEEE Transactions on Engineering Management, 61, 182-195. https://doi.org/10.1109/TEM.2013.2259494

Williams, J. D., \& Sofranko A. J. (1979). Motivations for the Inmigration Component of Population Turnaround in Nonmetropolitan Areas. Demography, 16, 239-255. https://doi.org/10.2307/2061141

Wish, N. B. (1986). Are We Really Measuring the Quality of Life? Well-Being Has Subjective Dimensions, As Well As Objective Ones. American Journal of Economics and Sociology, 45, 93-99. https://doi.org/10.1111/j.1536-7150.1986.tb01906.x

Yang, D. (2006). Why Do Migrants Return to Poor Countries? Evidence from Philippine Migrants' Responses to Exchange Rate Shocks. The Review of Economics and Statistics, 88, 715-735. https://doi.org/10.3386/w12396

Ziegler, J. A., \& Britton, C. R. (1981). A Comparative Analysis of Socioeconomic Variations in Measuring the Quality of Life. Social Science Quarterly, 62, 303-312. 